\title{
Innovative and Digital Development of the Economies of Ukraine and the European Union: Differentiations and Concept of the State Policy of Convergence
}

\author{
Marta Barna ${ }^{1}$, Svitlana Moroz ${ }^{2}$ \\ ${ }^{1}$ Lviv University of Trade and Economics, 10 Tugan-Baranosky Str, 79005 Lviv, Ukraine \\ ${ }^{2}$ Poltava branch of the National Scientific Center "Hon. Prof. M. S. Bokarius Forensic Science Institute», \\ 1/1 Churaivny Str, 36004 Poltava, Ukraine
}

\begin{abstract}
The author's methods of integrated assessment of the state of the innovative and digital development of the country's economy are developed. The methods are tested and the integral values of the innovative and digital development of the economy of Ukraine and the European Union in 2017-2019 are calculated. The rating of countries according to the integrated index of innovative and digital development is carried out. The comparative characteristic of the dynamics of change of the index of the innovative and digital development of the economy of Ukraine and the European Union is given. The strategic imperatives of the state policy of the convergence of the innovative and technological growth of the economy of Ukraine and the European Union are defined.
\end{abstract}

Keywords - economy's innovative and digital development, innovations, digital development, Ukraine and the EU.

\section{Introduction}

Ukraine has chosen a clear strategic vector of further economic and social development at the

DOI: $10.18421 /$ TEM102-25

https://doi.org/10.18421/TEM102-25

Corresponding author: Svitlana Moroz, Poltava branch of the National Scientific Center, 36004 Poltava, Ukraine

Email: svitmoroz@gmail.com

Received: 14 October 2020.

Revised: 20 April 2021.

Accepted: 27 April 2021.

Published: 27 May 2021.

(c) BY-NC-ND (C) 2021 Marta Barna \& Svitlana Moroz; published by UIKTEN. This work is licensed under the Creative Commons Attribution-NonCommercial-NoDerivs 4.0 License.

The article is published with Open Access at www.temjournal.com present stage of its development, which is closely correlated with the country's accession to the European Union and comprehensive European integration. The European Union is also interested in the closest cooperation in politics, justice, trade, economic and sectoral cooperation, finance, as evidenced by signing the Association Agreement between Ukraine and EU, as of June $27^{\text {th }} 2014$.

However, full and mutually beneficial integration is objectively impossible if its entities are at completely different levels of social and economic development. This is exactly the situation today when countries of the European Union have a significantly higher level of economic growth compared to Ukraine. To solve this problem, Ukraine needs to implement active reforms aimed at strengthening the competitiveness of the national economy, ensuring economic growth and economic convergence in comparison with the EU-27 countries. There is only one way to quickly implement such an ambitious plan - if a decisive course is chosen for the innovative and digital growth of Ukraine's economy based on the technological innovation and digital reforms of the economy.

To identify the state and structure of the innovative and digital development of the economy of Ukraine and the European Union, the author's methods are developed which provide the calculation of the integrated index of innovative and digital development, comparing its values in Ukraine and the EU-27 countries on average, identifying differentiation, both in general and by structural characteristics of the index, detecting factors that most influence Ukraine's lag behind the EU-27 countries in terms of the economy's innovative and digital development.

The practical application of the methods allows calculating integral values of the innovative and digital development of the economy of Ukraine and the European Union, ranking and grouping the 
countries according to the integrated index of innovative and digital development.

The specified information and analytical basis as well as the research results concerning the analysis of the current state of innovative and technological development, financial and resource potentialities of Ukraine, and also strategic directions of the national economy's further development allowed defining the strategic imperatives of the state policy of convergence of the innovative and digital development of the economy of Ukraine and the European Union, the implementation which will contribute to the acceleration of Ukraine's European integration.

\section{Literature Review}

An integral comprehensive characteristic of the ability of the state's economy to develop in today's globalized environment is its competitiveness. By forming basic principles and strengthening factors and conditions for ensuring the competitiveness of the domestic economy, the state becomes a regional leader [1], a center for attracting investment and industrial production intensification, employment guarantees and population welfare increase. At the same time, the formation of competitive positions requires the study of research results that identify relevant components [2].

As a result of analyzing several studies on economic growth and ensuring the economy's competitiveness, it is identified that increasingly prominent factors of competitiveness are becoming the following ones in today's world: industry's development 4.0 [3], smart-technologies [4], innovation and smart specialization [5]. The use of these and other factors as a whole allows ensuring the technological development of the national economy.

The formation of a high-quality and effective state policy to stimulate technological development is naturally based on the understanding of its directions and on the one hand, the factors that determine it. The study of the scientific publications in this area has given grounds to distinguish: stimulation of technological innovations [6], implementation of the technological modernization of industries [7], and development of the digital economy [8].

Information and analytical support is of extreme methodological and applied significance in the system of the state policy of the innovative and digital development management, firstly, assessment of the level of innovative and digital development; secondly, revealing "weaknesses" and weight of various factors influencing the formation of innovative and digital development; thirdly, the comparative analysis of the state of innovative and digital development of each country; fourthly, substantiation of priority areas of regulation and reforming; fifthly, forecasting and determining their effectiveness. When substantiating the methods of analyzing, a system of indicators is used. To form their composition, the existing and used developments on innovative and digital competitiveness [9], innovation index projecting [10], analyzing the creativity level of industries [11], [12], monitoring of innovative and digital development are analyzed [13], [14].

The development and testing of the methods with regard to analyzing allow drawing sufficiently extensive conclusions for further development of the provisions of a state policy to ensure the innovative and digital development of the national economy. At the same time, the quality of a state policy depends not only on national strategies and government programs but also on the potential of enterprises in the real sector of the economy. Therefore, when substantiating the tools and means of the state policy to ensure the innovative and digital development of Ukraine's economy and its convergence with the EU economy, it is necessary to take into account the research results in the field of transaction costs of the entrepreneurship technological development [15], problems of investing in technological innovations [16], ensuring the competitiveness of domestic goods in the domestic market [17].

\section{Aims}

The purpose of the study is to develop and test the methods for analyzing the state of the innovative and digital development of the national economy, as well as to check the hypothesis of the availability of significant divergence in the innovative and digital development of the economies of Ukraine and the European Union.

\section{Methods}

In the comprehensive assessment of the state of the innovative and digital development of the national economy, a system of indicators, which is selected for such purposes, is of paramount importance. It is important to consider some aspects. Firstly, it is a sufficiently wide range of indicators for the comprehensive analysis of the problem. Secondly, it is the availability of several qualitative characteristics besides the quantitative ones. Thirdly, it includes taking into account not only statistical data but also the opinions of recognized experts.

Given the above information, it is concluded that the best use for the integrated analysis of the status of the innovative and digital development of the economy of indicators is by applying the leading 
world's rankings in this area. Thus, the current data, which are presented within the Global Innovation Index and the Digital Competitiveness Index of the Swiss Institute for Management Development, were selected as indicators. In particular, the Global Innovation Index provides the following indicators: institutions, human capital and research, innovation infrastructure, quality of the market environment, business relations with the entities of innovation and technology, application of knowledge and technology in the economy, results of intellectual creativity. The World Digital Competitiveness Index includes the data on digital knowledge, digital technologies, and the country's readiness to develop the digital economy. Thus, ten indicators were used that correspond to the complex characteristics of the innovative and digital development of the state's economy.

The information base of the analysis included the values of the sub-indices of the Global Innovation Index and the Digital Competitiveness Index for Ukraine and the EU-27 countries in 2017-2019.

Fig. 1 shows the author's methodological sequence used for the integrated assessment of the state of the national economy's innovative and digital development.

It should be noted on the two most important aspects of the calculations. This is, firstly, the determination of weighted coefficients of the indicators. The method of principal components is used for that - a kind of factor analysis, which allows calculating the total impact on the resulting feature of the whole array of factors, among which the main components are distinguished, based on which weights of the other components are determined. Secondly, it is the identification of ultimate limits sample (given the state of technological development) values of indicators, which will be compared with the actual values of indicators for each country. For such purposes, it is appropriate to use the values among the countries that were the highest in a particular year for a particular indicator.

\section{Results}

The identified weights of indicators of the state of the economy's innovative and digital development are shown in Fig. 2. It can be concluded from the obtained results that all the characteristics significantly determine the state of the national economy's innovative and digital development. However, they define the ability of public authorities to intensify the processes of digitalization of the economy and society, the infrastructure development to support innovative and technological activity, and the quality of staffing coverage of the digital development.

Formation of a database of indicators by the sub-indices of the Global Innovation Index and the World Index of

Digital Competitiveness for a certain period of time

Standardization of indicators; calculation of weighted coefficients of the indicators using the method of principal components

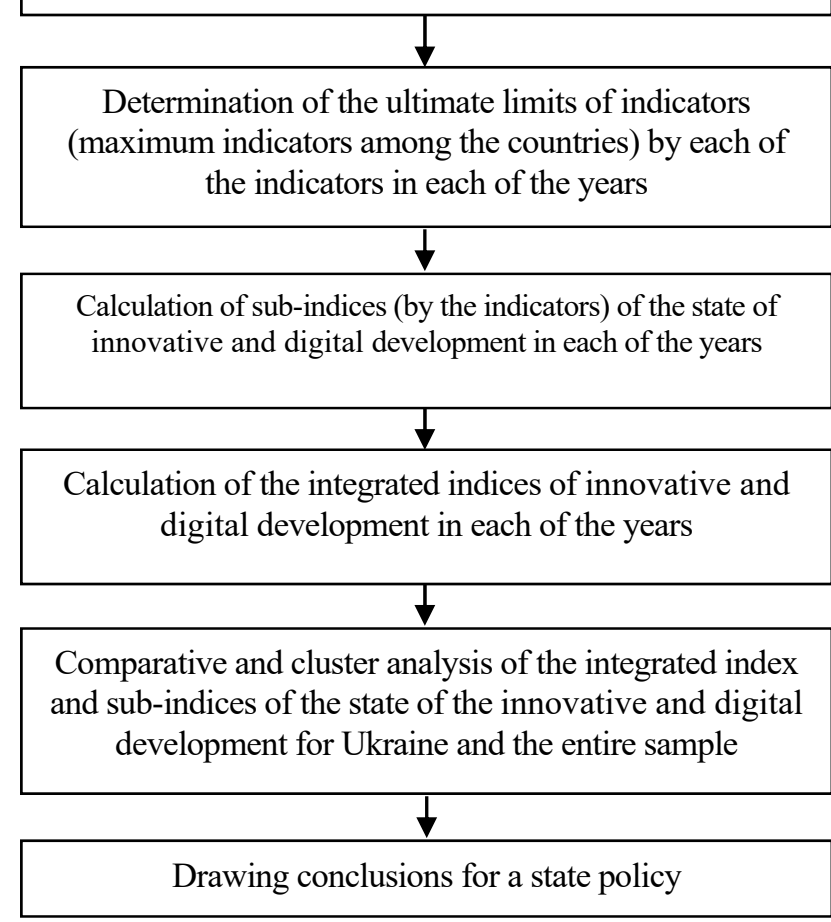

Figure 1. General sequence of the methodology of integrated assessment of the state of the national economy's innovative and digital development (author's development)

This confirms the high relevance of the development of the digital sector of the economy and the institutional subjects of innovative and digital activity. These are the priority steps that should be implemented to improve the state of the innovative and digital development of the country's economy.

Table 1 shows the results of calculating the integrated index of the innovative and digital development of the EU-27 and Ukraine in 20172019. The calculations confirmed its very low level for the economy of Ukraine. In 2019, the value of the integrated index for the economy of Ukraine was 0.53 , which was the lowest among the analyzed countries. 


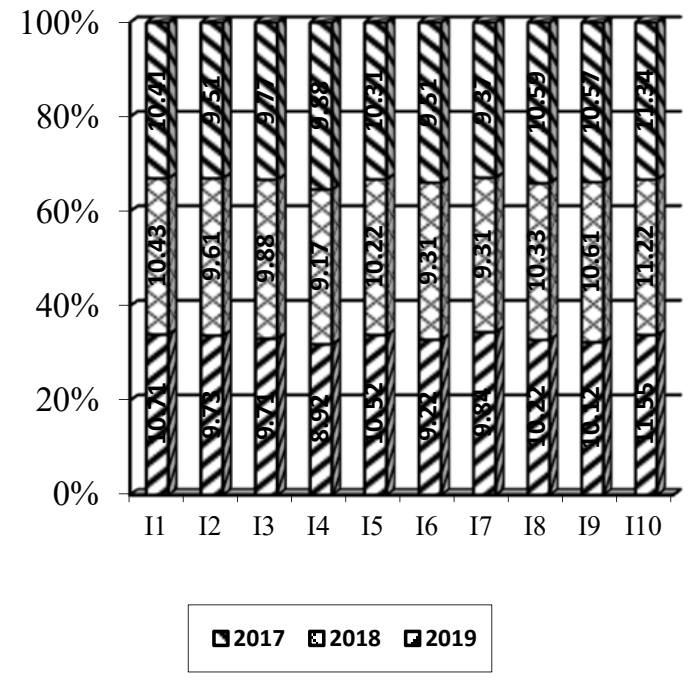

Note: $I_{1}-$ institutions, $I_{2}-$ human capital and research, $I_{3}-$ innovation infrastructure, $I_{4}$ - quality of the market environment, $I_{5}$ - business relations with the entities of innovation and technology, $I_{6}$ - results of the use of knowledge and technology in the economy, $I_{7}$ - results of intellectual creativity, $I_{8}-$ digital knowledge, $I_{9}$ - digital technologies, $I_{10}$ - country's readiness for the growth of the digital economy

Figure 2. Weights of the indicators of the state of the economy's innovative and digital growth (calculated by the authors)

Herewith, the lowest value among the EU-27 was in Romania (0.541). The indicator for this country exceeded the value for Ukraine by 0.01 . Finland was characterized by the highest level of technological development.

There was a notable situation when most of the analyzed countries improved their position in terms of the economy's innovative and digital growth in 2019 compared to 2017.

Among the EU-27 countries, the countries characterized by the highest level of innovative and digital development, in 2017-2019 the largest increase in the integrated index occurred in Finland $(6.85 \%)$, France $(1.89 \%)$, and Spain $(2.22 \%)$. Instead, the decline (although only within 1-2\%) of the integrated index in Sweden, the Netherlands, Denmark, Ireland, Luxembourg, and Austria was typical. The situation indicates that in recent years there has been a trend towards more active innovative and digital development of countries that are somewhat inferior in terms of economic growth and equalization, thus, the innovative and digital development of the EU economy in the territorial aspect.
Table 1. Integrated indices of the state of the innovative and digital development of the EU and Ukraine in 2017 2019 (calculated by the authors)

\begin{tabular}{|l|c|c|c|c|c|}
\hline \multirow{2}{*}{ Countries } & \multicolumn{3}{|c|}{ Years } & \multicolumn{2}{c|}{ Deviation } \\
\cline { 2 - 6 } & 2017 & 2018 & 2019 & $\begin{array}{c}\text { absolute } \\
2019 / \\
2017, \\
+/-\end{array}$ & $\begin{array}{c}\text { relative } \\
2019 / \\
2017, \%\end{array}$ \\
\hline Finland & 0.853 & 0.910 & 0.911 & 0.06 & 6.85 \\
\hline Sweden & 0.914 & 0.918 & 0.906 & -0.01 & -0.84 \\
\hline Netherlands & 0.892 & 0.891 & 0.886 & -0.01 & -0.66 \\
\hline Denmark & 0.888 & 0.893 & 0.877 & -0.01 & -1.23 \\
\hline France & 0.824 & 0.840 & 0.840 & 0.02 & 1.89 \\
\hline Germany & 0.812 & 0.824 & 0.817 & - & 0.51 \\
\hline Ireland & 0.811 & 0.814 & 0.808 & - & -0.37 \\
\hline Luxembourg & 0.788 & 0.789 & 0.773 & -0.01 & -1.89 \\
\hline Austria & 0.771 & 0.788 & 0.768 & - & -0.51 \\
\hline Belgium & 0.753 & 0.759 & 0.755 & - & 0.22 \\
\hline Czech & 0.752 & 0.759 & 0.740 & -0.01 & -1.59 \\
Republic & 0.724 & 0.734 & 0.740 & 0.02 & 2.22 \\
\hline Spain & 0.718 & 0.735 & 0.715 & - & -0.47 \\
\hline Estonia & 0.718 & - & \\
\hline Italy & 0.699 & 0.703 & 0.698 & - & -0.14 \\
\hline Portugal & 0.665 & 0.680 & 0.673 & 0.01 & 1.28 \\
\hline Slovenia & 0.636 & 0.655 & 0.665 & 0.03 & 4.41 \\
\hline Malta & 0.621 & 0.651 & 0.662 & 0.04 & 6.61 \\
\hline Cyprus & 0.603 & 0.628 & 0.644 & 0.04 & 6.80 \\
\hline Latvia & 0.606 & 0.615 & 0.616 & 0.01 & 1.63 \\
\hline Croatia & 0.583 & 0.616 & 0.615 & 0.03 & 5.52 \\
\hline Poland & 0.574 & 0.600 & 0.609 & 0.04 & 6.25 \\
\hline Slovakia & 0.593 & 0.599 & 0.609 & 0.02 & 2.72 \\
\hline Hungary & 0.586 & 0.560 & 0.609 & 0.02 & 3.95 \\
\hline Lithuania & 0.605 & 0.601 & 0.599 & -0.01 & -1.03 \\
\hline Bulgaria & 0.552 & 0.576 & 0.588 & 0.04 & 6.54 \\
\hline Greece & 0.571 & 0.584 & 0.583 & 0.01 & 2.22 \\
\hline Romania & 0.502 & 0.535 & 0.541 & 0.04 & 7.82 \\
\hline EU & $\mathbf{0 . 7 0 7}$ & $\mathbf{0 . 7 2 0}$ & $\mathbf{0 . 7 1 9}$ & $\mathbf{0 . 0 1}$ & $\mathbf{1 . 6 9}$ \\
\hline Ukraine & $\mathbf{0 . 4 5 7}$ & $\mathbf{0 . 5 2 2}$ & $\mathbf{0 . 5 2 9}$ & $\mathbf{0 . 0 7}$ & $\mathbf{1 5 . 6 5}$ \\
\hline \hline & & & & & \\
\hline
\end{tabular}

Regarding Ukraine, the level of the economy's innovative and digital development increased by $15.65 \%$ in $2017-2019$, which was positive. However, Ukraine's economy still has not reached the level of the last country of the EU economy in this ranking Romania, which over the past 2 years has also improved the value of its integrated index (by $7.82 \%)$.

During 2017-2019, the integral value of the index of the state of the innovative and digital development of the analyzed countries increased (Fig. 3). If in 2017 the indicator was 0.707 , in 2018 it increased to 0.721 (by 0.014 ), and in 2019 - to 0.719 (by 0.012 more than in 2017).

The growth of the index was more noticeable for Ukraine. This is a positive feature, but due to the data, the level of the innovative and digital development of Ukraine's economy continues to be 
significantly inferior to the integral value. As of 2019, the difference was 0.19 (or about $35 \%$ ), which is significant.

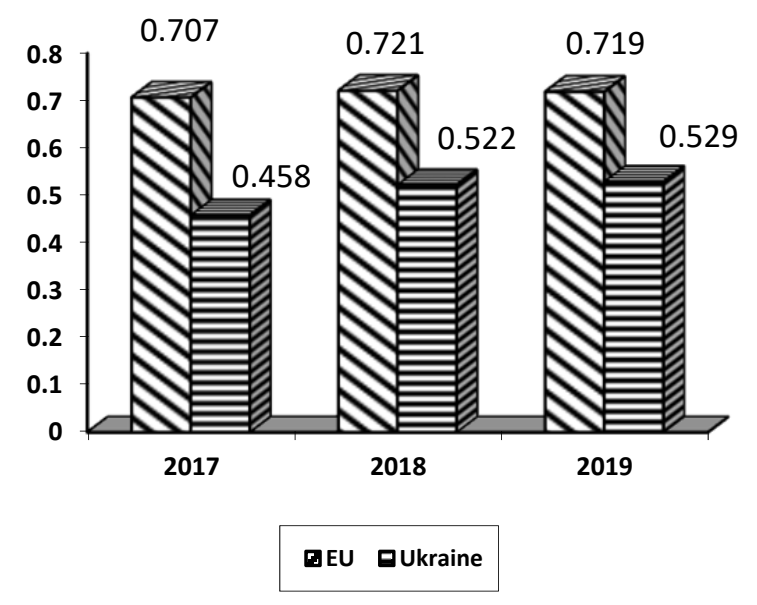

Figure 3. Integrated indices of the state of the innovative and digital development of the EU-27 countries and Ukraine in 2017-2019 (calculated by the authors)

Thus, the level of innovative and digital development of Ukraine's economy is low. On the other hand, if the digital economy development intensifies, Ukraine can overcome the gaps in innovative and digital development much faster compared to higher-tech economies. Achieving this task requires the implementation of a set of tools in the following directions: direction 1 intellectualization of the economy (smart specialization, creation, new knowledge); direction 2 - digitalization of the economy and society (digital society, digital state, digital business and market); direction 3 - technological modernization of production (innovative technologies).

Based on the calculated data on the integrated indices of the innovative and digital development of the national economies of Ukraine and the EU-27, the grouping of countries is carried out (Table 2).

The division of the countries into five groups according to the integral values of the innovative and digital development index is identified. Ukraine together with Romania forms a group characterized by a critically low level of innovative and digital development of the national economy. Moreover, the values of Euclidean distances for these countries turn out to be the same. Accordingly, Ukraine and Romania are significantly inferior to other EU countries in almost all the indicators that were taken into account when calculating the integrated index.

Most of the indicators of the integrated index of innovative and digital development also remain low for the economies of countries such as Hungary, Lithuania, Bulgaria, Greece, and Slovakia.
Table 2. Results of the cluster analysis of grouping of the EU-27 countries and Ukraine by the integrated index of the innovative and digital development of the economy in 2019 (calculated by the author using Statistica 7 software)

\begin{tabular}{|c|c|c|c|}
\hline $\begin{array}{l}\text { Group } \\
\text { number }\end{array}$ & \begin{tabular}{|l} 
Euclidean \\
distances
\end{tabular} & Countries & Group characteristics \\
\hline \multirow[b]{2}{*}{1} & 5.231 & Ukraine & \multirow{2}{*}{$\begin{array}{c}\text { Critically low level of } \\
\text { innovative and digital } \\
\text { development }\end{array}$} \\
\hline & 5.231 & Romania & \\
\hline \multirow{5}{*}{2} & 2.242 & Hungary & \multirow{5}{*}{$\begin{array}{l}\text { Economies with a low } \\
\text { level of innovative and } \\
\text { digital development }\end{array}$} \\
\hline & 3.374 & Lithuania & \\
\hline & 5.115 & Bulgaria & \\
\hline & 3.587 & Greece & \\
\hline & 2.306 & Slovakia & \\
\hline \multirow{9}{*}{3} & 4.581 & Italy & \multirow{9}{*}{$\begin{array}{c}\text { Economies with a } \\
\text { medium level of } \\
\text { innovative and digital } \\
\text { development }\end{array}$} \\
\hline & 4.737 & Cyprus & \\
\hline & 5.026 & Malta & \\
\hline & 4.391 & $\begin{array}{c}\text { Czech } \\
\text { Republic }\end{array}$ & \\
\hline & 4.627 & Latvia & \\
\hline & 3.862 & Croatia & \\
\hline & 2.979 & Poland & \\
\hline & 3.170 & Portugal & \\
\hline & 3.751 & Slovenia & \\
\hline \multirow{6}{*}{4} & 3.940 & Belgium & \multirow{6}{*}{$\begin{array}{l}\text { Economies with the } \\
\text { level of innovative and } \\
\text { digital development } \\
\text { above average }\end{array}$} \\
\hline & 4.700 & Estonia & \\
\hline & 4.989 & Spain & \\
\hline & 4.807 & Ireland & \\
\hline & 7.737 & Luxemburg & \\
\hline & 5.865 & Austria & \\
\hline \multirow{6}{*}{5} & 4.391 & Denmark & \multirow{6}{*}{$\begin{array}{l}\text { Economies with the } \\
\text { highest level of } \\
\text { innovative and } \\
\text { technological } \\
\text { development }\end{array}$} \\
\hline & 4.627 & Germany & \\
\hline & 3.862 & France & \\
\hline & 2.979 & Netherlands & \\
\hline & 3.170 & Finland & \\
\hline & 3.751 & Sweden & \\
\hline
\end{tabular}

But, at the same time, an important practical conclusion (for Ukraine) is that at the first stage of the innovative and digital development of its economy it is necessary to try to increase its level to the level of the countries in the groups of low and medium levels of innovative and digital development.

After all, it is impossible to immediately reach the level of innovative and digital development, like, for example, in the economies of countries that consistently find themselves in the group above the average and the highest level of innovative and digital development.

Such tasks can be objectively set only in the medium and long term. Still, all EU economies are pursuing active policies to support and intensify the innovative and digital development of the national economy, which should become an example for Ukraine.

The formation and implementation of the state policy to stimulate the innovative and digital development of the economy for the convergence of the economic development of Ukraine and the EU should be a strategic and planned process. Accordingly, the authors are talking about the development of a national concept, the basic provisions of which are presented in Table. 3 . 
Table 3. Structure of the Concept of the state policy of the innovative and digital development of Ukraine's economy (author's development)

\begin{tabular}{|c|c|}
\hline $\begin{array}{l}\text { Structural } \\
\text { elements of } \\
\text { the Concept }\end{array}$ & Basic provisions \\
\hline 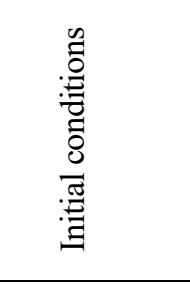 & $\begin{array}{l}\text { - At the current stage of development, } \\
\text { Ukraine's economy has significantly reduced } \\
\text { its innovation and digital potential, which } \\
\text { threatens to further lag behind the EU } \\
\text { economy, does not contribute to the } \\
\text { convergence and economic European } \\
\text { integration of Ukraine's economy }\end{array}$ \\
\hline 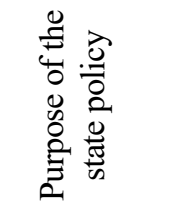 & $\begin{array}{l}\text { - Improving the system of formation and } \\
\text { implementation of the innovation and digital } \\
\text { potential of the national economy, ensuring a } \\
\text { high level of its resistance to the influence of } \\
\text { factors and conditions of globalization }\end{array}$ \\
\hline 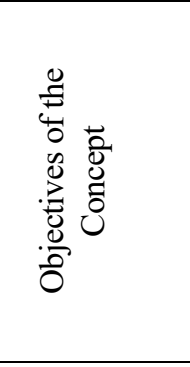 & $\begin{array}{l}\text { - Ensuring macroeconomic self-sufficiency; } \\
\text { - formation of the stability and solvency of a } \\
\text { financial system; } \\
\text { - achieving energy independence and } \\
\text { efficiency; } \\
\text { - formation of the infrastructure of } \\
\text { innovation and digital development; } \\
\text { - development of the intellectual property } \\
\text { market }\end{array}$ \\
\hline 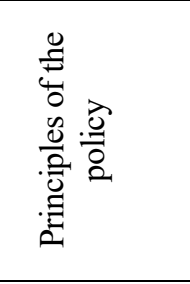 & $\begin{array}{l}\text { - Planning and consistency; } \\
\text { - systematicity and complexity; } \\
\text { - preventive; } \\
\text { - focus on state economic interests; } \\
\text { - priority of measures to ensure the } \\
\text { competitiveness of the economy and } \\
\text { effective functioning of the internal market }\end{array}$ \\
\hline 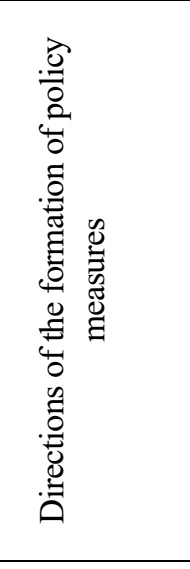 & $\begin{array}{l}\text { - Initiation of monitoring, analysis, and } \\
\text { diagnostics of innovative and digital } \\
\text { development; } \\
\text { - implementation of strategizing and policy } \\
\text { planning taking into account external and } \\
\text { internal conditions and opportunities; } \\
\text { - improvement of the organizational and } \\
\text { managerial system of innovative and digital } \\
\text { development; } \\
\text { - introduction of an organizational and } \\
\text { economic mechanism for the realization of } \\
\text { economic interests of the real sector; } \\
\text { - establishment of a system of quality control } \\
\text { and efficiency of the system }\end{array}$ \\
\hline 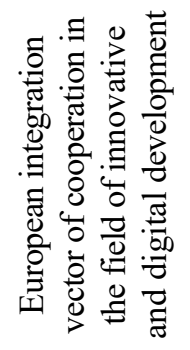 & $\begin{array}{l}\text { - Ensuring comprehensive European } \\
\text { integration; } \\
\text { - development of foreign economic } \\
\text { cooperation systems; } \\
\text { - accelerating participation in Euro-Atlantic } \\
\text { unions; } \\
\text { - attracting external financial and investment } \\
\text { support }\end{array}$ \\
\hline
\end{tabular}

Under the above approach, there are grounds to identify the improvement of the system of the formation and implementation of the innovation and digital potential of the national economy, ensuring a high level of its resistance to the factors and conditions of globalization as a goal of the state policy.

Collectively, the implementation of the goal will ensure the formation of a reliable system of stimulating innovative and digital development that can withstand complex problems. Moreover, it is the systemic nature and approach that guarantee the safe development of the national economy and its enterprises, protection, and resilience from modern hybrid threats.

Defining such targets allows implementing purposeful state policy in various functional components of innovative and digital development, and at the same time in key spheres of life (economy, financial sector, social sphere, power engineering, regional development, etc.), which encourages both business and public, and state establishments to orient, give priority to the common goal strengthening the innovation and digital competitiveness of the national economy.

The development and subsequent implementation of the Strategy for innovative and digital growth should become an integral addition to the Concept of the innovative and digital development of the economy of Ukraine. Such a document would be a logical continuation of the detailing and institutionalization of the Concept, as well as a guide for planning and implementing a state policy and a basis for developing regional and sectoral strategies and programs in the field of innovative and digital development.

It is necessary to talk about two basic vectors of the Strategy:

1) Modernization of the system of support of the innovative and digital development of Ukraine's economy (its relevance is due not only to the need to modernize and strengthen the capacity of such a system, but also the fact that such a system in the state is not institutionalized yet, there is no common vision of its organizational and managerial structure and a set of elements, its functions and connections, relationships between them, appropriate incentives and motives for rational behavior and, conversely, control and creation of "safeguards" of deviant behavior, the development of negative trends);

2) Strategizing of the state policy in the field of innovative and digital development, within which the strategic goals and objectives, responsible executors, as well as specific measures for the implementation of the strategy, their financial and resource support, will be determined. 


\section{Conclusion}

The approbation of the author's methods of calculating the integrated index of the state of the innovative and digital development of the economy confirmed the hypothesis that the level of innovative and digital development of Ukraine's national economy is low and significantly inferior to similar characteristics of the EU-27 countries and this is one of the obstacles to the rapid European integration of Ukraine, in particular in the economic plane. In 2017-2019, the level of the innovative and digital development of Ukraine's economy increased from 0.458 to 0.529 . However, in 2019, the integrated index of the state of the innovative and digital development of the EU-27 economy was 0.719, which was $35.9 \%$ more than for Ukraine. The gap in technological development remains critically high.

To minimize the divergence in the innovative and digital development of the economies of Ukraine and the European Union (as an integral factor in intensifying the processes of Ukraine's European integration) in Ukraine, it is necessary to adopt the Concept, Strategy, and programs of the innovation and digital development of the national economy.

The strategic priorities of state regulation of the innovative and digital development of the national economy should be aimed at overcoming the factors causing the economy's unpreparedness for competition in terms of accelerating innovation and digital activity and the development of an information economy and focus on achieving the strategic goal of state policy in this area strengthening the external and internal innovative and digital competitiveness of the economy through the development of internal competition and strengthening the competitiveness of production based on advanced digital innovations and information technologies, system support of elements of the innovation infrastructure, formation and implementation of the intellectual and personnel potential of innovative and digital development.

\section{References}

[1]. Aranguren, M. J., Magro, E., \& Wilson, J. (2017). Regional competitiveness policy in an era of smart specialization strategies (pp. 546-564). Edward Elgar Publishing.

[2]. Skrypnyk, Nataliia Ye., and Sydorenko, Kateryna V. (2019) "The Key Components in Forming a Modern Innovation Basis of Competitiveness in the Context of Globalization Transformations." Business Inform 4, 115-123.

[3]. Bailey, D., \& De Propris, L. (2019). 6. Industry 4.0, Regional Disparities and Transformative Industrial Policy. Regional Studies Policy Impact Books, 1(2), 67-78. doi.org/10.1080/2578711X.2019.1621.

[4]. Balland, P. A., Boschma, R., Crespo, J., \& Rigby, D. L. (2019). Smart specialization policy in the European Union: relatedness, knowledge complexity and regional diversification. Regional Studies, 53(9), 1252-1268. Doi: 10.1080/00343404.2018.1437900.
[5]. Carayannis, E., \& Grigoroudis, E. (2016). Quadruple Innovation Helix and Smart Specialization: Knowledge Production and National Competitiveness. Foresight and STI Governance (Foresight-Russia till No. 3/2015), 10(1), 31-42. Doi: 10.17323/1995-459x.2016.1.31.42.

[6]. Brown, R. L. (1994). Technological innovation's impact on market structure and industry profitability. The Journal of High Technology Management Research, 5(1), 123-140.

[7]. Buzhymska, K. (2011). Some components of the theoretical and methodological basis of innovative technological modernization. Bulletin of Zhytomyr State Technological University, 50(4), 113-119.

[8]. Edsand, H. E. (2019). Technological innovation system and the wider context: A framework for developing countries. Technology in Society, 58, 101150.

[9]. Vasyltsiv, T., Irtyshcheva, I., Lupak, R., Popadynets, N., Shyshkova, Y., Boiko, Y., \& Ishchenko, O. (2020). Economy's innovative technological competitiveness: Decomposition, methodic of analysis and priorities of public policy. Management Science Letters, 10(13), 3173-3182.

[10]. Dutta, S., Lanvin, B., \& Wunsch-Vincent, S. (2019). The global innovation index 2018: Energizing the world with innovation. Cornell University, INSEAD, and WIPO.

[11]. Correia, C. M., \& da Silva Costa, J. (2014). Measuring Creativity in the EU Member States. Investigaciones Regionales-Journal of Regional Research, (30), 7-26.

[12]. Rusu, M. (2013). Smart specialization a possible solution to the new global challenges. Procedia Economics and Finance, 6, 128-136. Doi: 10.1016/S2212-5671(13)00124-X.

[13]. Kleibrink, A., Gianelle, C., \& Doussineau, M. (2016). Monitoring innovation and territorial development in Europe: emergent strategic management. European Planning Studies, 24(8), 1438-1458. Doi: 10.1080/09654313.2016.1181717.

[14]. Thissen, M., Van Oort, F., Diodato, D., \& Ruijs, A. (2013). Regional competitiveness and smart specialization in Europe: Place-based development in international economic networks. Edward Elgar Publishing.

[15]. Vasyltsiv, T. G. (2015). Areas of improvement of the institutional basis for minimizing the transaction costs of business entities in Ukraine. Actual Problems of Economics, 10 (172), 160-169.

[16]. Ilyash, O., Yildirim, O., Smoliar, L., Doroshkevych, D., Vasylciv, T., \& Lupak, R. (2020). Evaluation of enterprise investment attractiveness under circumstances of economic development. Bulletin of Geography. Socio-economic Series, 47(47), 95-113. Doi: 10.2478/bog-2020-0006.

[17]. Vasyltsiv, T. H., \& Lupak, R. L. (2016). Strategic priorities of state structural policy of import substitution in Ukraine. Aktual'ni problemy ekonomiky, (1), 52-60. 